\title{
Analysis of Innovative Talents Cultivation for Dialogue Education in "Internet Plus" Era
}

\author{
Bei He \\ Heihe University \\ Heihe, China
}

\begin{abstract}
The generation of Internet brings about a tremendous change to the world, and the Internet development presents a new trend with the presentation of the concept of "Internet plus". "Internet plus" is the advancement of Internet thinking and the fusion of Internet and various industries. Such integration is extremely apparent in education. Under the guidance of student-oriented education ideology, equal dialogue between teacher and students is required in our education. "Internet plus" can make such dialogue be realized in a more effective way. As a result, our major topic is to discuss how to perform dialogue education better using "Internet plus" to cultivate innovative talents for the society.
\end{abstract}

Keywords-Internet plus; dialogue education; innovation; talents cultivation

\section{INTRODUCTION}

The new era features the generation of large amount of information and rapid transmission of it. The Internet technology grows by leaps and bounds, thus more innovative and compound talents are needed. With the arrival of the era of Internet, the "Internet+" era in particular, new requirements for education are put forward. Dialogue education is an important education method, so how to cultivate the innovative talents meeting the requirements of "Internet + " by virtue of dialogue education is a significant problem to be solved for education.

\section{CONNOTATION OF "DiAlogUE EDUCATION"}

The word "dialogue" is often mentioned in recent years and is widely used in various fields, especially in education as "dialogue education" is proposed, which has demonstrated the development trend of current education. In traditional education, the dominant position of teacher in teaching process is advocated. Students are passive in the process, and their activity and mobility are neglected. "Dialogue education" stresses equal position of teacher and students in their learning process, and this process is a dialogue with teacher, but not receiving knowledge in a passive way, which has broken the traditional teacher-student pattern and is favored by students.

"Dialogue education" is advocated by humanism, and its essence is to give expression to the value of human, to conduct the "dialogue" in a mutual respect and mutual trust way on the basis of equality. By dialogue, individual's subjective initiative can be mobilized, and the individual can be spurred to communicate with the outside world actively, but not acquire passively. This is the dialogue in true sense instead of the passive learning dominated by teacher. Only in this way can the passive learning be turned to an active one.

The core of "dialogue education" is "dialogue. What is the "dialogue" in education? It refers to a process in which the educator and the educated perform a two-way communication through language or other medium in an equal learning environment, so as to enable the educated to obtain new knowledge or new skills. The teacher-student dialogue enables them to exchange ideas, discuss problems, and eventually realize their objective through mutual effect and influence, common participation and intimate cooperation. It can be seen from the above the importance of "dialogue" to education.

\section{ORIGIN OF "DiAlogue EDUCATION”}

As a kind of unique teaching method of education, dialogue education is studied by many scholars both at home and abroad, obtaining a lot of law that are worth to be promoted

\section{A. "Dialogue Education” in Foreign Countries}

As we all know, there were many philosophers in ancient Greek, and they were keen on philosophical debate at that time. And dialogue became the important way for these scholars to make idea exchanges and academic research. Among them, the famous philosopher Socrates was the first one who applied dialogue into teaching, and he named his teaching method as "midwife", with the meaning of enlightening and guidance. Nowadays, we regard "midwife" as the rudiment of "dialogue education". The "midwife" adopted by Socrates lies in the guidance in regular order, aiming to mobilize the activity of students, offer them the feeling of being respected and they have equal position with the teacher, they can express ideas without restrictions. Therefore, the teacher can discuss and seek truth together with students in the free environment. Such education ideology is still an advanced educational concept today, and a state to understand the mind of students.

Afterwards, many other philosophers, thinkers and educators continued the development of "dialogue education". For example, the educator M.M. Bakhtin deepened the research of "dialogue education" from the perspective of humanistic care, stressed that education was the cultural and psychological activities for educating people, the soul and the moral character, the communication of mind and the 
agreement of spirit between people and the people-to-people communication activities. [1] Martin Buber, a philosopher, religious scholar, theologian, is renowned as "father of dialogue theory". He pointed out that all humans existed in different relations in this world, including "I-you" relation and "I-it" relation. [2]That indicates that humans influence each other. In the teaching process, both teacher and students interact as the subject to perform the dialogue and form a certain relation. Paulo Freire applied the dialogue theory into education, and put forward dialogue teaching and liberated views on education. He emphasized that in dialogue education, teacher should regard student as his partner with active thinking and response to the teacher. Their communication may be furthered by subjective idea expression, so as to reflect the subject position of student in true sense. [3]In addition, John Dewey, Jean Piaget and others revealed the meaning of dialogue in education from different perspectives and levels.

\section{B. "Dialogue Education" in China}

As early as 2000 years ago, educators in China displayed the "dialogue education" using their own education method. The Analects of Confucius records the dialogue between Confucius, the greet educator of China, and his students, and this is the most persuasive evidence of dialogue education. Confucius conducted his teaching by "benevolence", advocated "not to explain unless one is desperately anxious to learn, nor to explain if one doesn't determine to learn". During each conversation and debate with students, he did not tell students the truth directly, but guided students to think, explore and comprehend the principles contained in it. "Learning without thought means labor lost; thought without learning is perilous" the idea of Confucius recorded in The Analects of Confucius, and this denotes that Confucius attached great importance to "learning" and "thought", which is the quintessence of elicitation teaching method of Confucius, and a different way to achieve the results of "midwife" of Socrates. In addition, both the educator Cai Yuanpei and the writer Lu $\mathrm{Xu}$ in China agreed with the dialogue education method, advocating to reflect humanistic care and to pay attention to the development of human in the process of education.

\section{FEATURES OF DiAlogue EdUCATION IN "INTERNET PLUS" ERA}

As the main channel for information communication in the 21 st century, Internet has penetrated in people's daily life. Currently, China is advocating "Internet+" vigorously, which has also put forward new requirements for education, and offered the chance for further innovation of education and the opportunity for development of education.

\section{A. Openness of Dialogue Education in "Internet Plus" Era}

The Internet has created an era, but it has also changed people's daily life, work and study. The education in family, school and society also relates to the existence of Internet, thus it can be seen that the Internet influences the development and progress of society. The arrival of "Internet+" era also has significant effect on "dialogue education". Internet is characterized by openness, which is also the important factor influencing dialogue education. The form of openness is of more openness thanks to the openness of Internet technology. Such openness not only reflects in the openness of time and space, but also in the openness of target and content of dialogue. The range and depth of education may be expanded using relevant technologies of Internet by dialogue education, and this is a powerful support for further development of dialogue education. The generation of various interactive software and application for chatting supported by Internet technology provides more convenient conditions for such openness.

Through the Internet and relevant software, the communication and interaction between teacher and teacher, teacher and student, student and student is not limited to face to face. Whether the dialogue is real time or not, the communication between the two parties can be ensured, thus an effective dialogue can be performed. In the "Internet+" era, dialogue education is not limited to the teacher-student dialogue in classroom, but the dialogue at all times and places in the daily life in most of the cases, providing freer time and wider space for the dialogue education. Moreover, the object of dialogue can be the teacher and students who know each other very well, the "classmates" newly acquainted on the Internet, and even the strangers; the object also can be the compatriots of a same country, the friends from all over the world; they can realize dialogue via the platform of Internet. Such dialogue is conductive to the sharing of information, enabling both teachers and students to make progress by learning from each other and complement each other. Such openness of dialogue education contributes more to the cultivation of students' divergent thinking and innovative ability as well as the cultivation of innovative talents.

\section{B. Multivariate Dialogue Education in "Internet Plus"}

The dialogue education in the early stage mainly relies on face-to-face communication between humans. With the progress of Internet technology, the telecommunication technology and tools such as microwave and telephone, the scope of dialogue education is expanded and developed. Entering into the era of "Internet + ", people have more diversified methods to communicate, and more technologies and tools are applied in the education industry on the basis of existing condition, so that more tools can be used to perform dialogue teaching. The educator can also change his teaching method and select different technologies and tools for dialogue education. As a result, dialogue education is of diversified expression ways and enters into the multivariate development era.

The traditional dialogue education is carried out in class, stressing the one-to-one dialogue between teacher and student. Such dialogue with class as a unit has a small scale, and the role of teacher cannot be given into full play, wasting the educational resources. The current online class, however, has broken this phenomenon and expanded the scale of education, enabling one teacher to face more students from multiple countries, regions and classes, maximizing the educational resources. By such new-type teaching method, dialogue can be carried out both online and offline, which is more conductive to the collision of ideas between the dialogue subjects, and to form the brainstorming. The dialogue education in the 
"Internet+" era has broken the limitation in traditional teaching in classroom, and the multivariate teaching pattern is formed. For instance, students from different classes of different countries can learn the same course offered by the same teacher, and students from the same class of the same country can learn different courses offered by different teachers. Different teachers and different students can communicate with each other whenever and wherever possible. Such dialogue has a large scale of subjects, abundant information, free dialogue space and time, thus the dialogue education is multivariate. That is beneficial to the dialogue between student and various types of people, which can broaden students' horizon and is advantageous to the formation of innovative thinking. In addition, this is also of significant meaning for the cultivation of innovative talents.

\section{ENLIGHTENMENT OF INNOVATIVE TALENTS Cultivation By Dialogue Education in "INTERnet Plus" ERA}

China advocates "Internet+" pattern vigorously since the entrance in Internet era. The operation type of Internet offers people convenience to acquire more information. Dialogue education supported by Internet carries out activities for learning by online-offline combination, so it receives attention from teachers and students and becomes the favor of them, and it is bound to be the main teach mode. Dialogue education provides new solution for the individualized learning for students, and becomes a new challenge of the traditional education. There are multiple communication ways under the Internet environment, such as MicroBlog, WeChat, QQ and other immediate interaction software, as well as multiple teaching platforms, such as Chaoxingera, Chaoxingfanya, Zhihuishu, Moso Teach and other online teaching class platforms. The introduction of them into the dialogue education will promote better performance of dialogue education, provide platform and technology for implementation of dialogue education, and create favorable conditions for the cultivation of innovative talents in the future.

\section{A. "Internet Plus" Lays Foundation for Innovative Talents Cultivation in Dialogue Education}

Internet is the powerful technology in the 21 st century, and has promoted the transformation of every aspect of the society. In addition, it has provided multiple choices for the transmission of education information. People can acquire knowledge in a more convenient way thanks to the popularization of Internet technology, so learners can obtain knowledge through both the traditional and modern ways. Facing the new technology and the change of ways, dialogue education should be reformed accordingly, thus the information about education can be transmitted in a better way and the interaction between teacher and students can be realized. The constantly reformed technology has promoted people's demand for innovation. China has advocated innovative education vigorously since the "12th Five-year Plan", and "Internet+" has just satisfied people's demand for innovation, providing the solid technique support for innovative talents cultivation in a better way.
MOOC, namely the massive open online courses, is an online learning platform established by American universities. With the free courses provided online, students can select the course according to their own interest, which courses include video, exercises and other resources for teachers, and online and offline discussion, mentoring organized for students. Such teaching pattern not only guarantees the normative management of class teaching, but also shares course resources. Many non-formal online learning platforms also emerge in China based on the form of MOOC. "Internet + " enables the information transmission channel of dialogue education to be further reformed, and the emergence of these sharing courses has paved way for innovative talents cultivation by dialogue education.

\section{B. "Internet Plus" Promotes the Transformation of Innovation Method in Dialogue Education}

The Internet development has facilitated the development of dialogue education effectively. The combination of Internet and education, especially dialogue education, is realized by real-time interactive communication software, online course platform and other communication methods. This is advantageous to the improvement of teaching quality and cultivation of the desired innovative talents by China and the society. "Internet+" is a powerful sword for remolding, recreation and establishment of education. The introduction of "Internet+" into dialogue education will give rise to a reform in the innovative method of education. As a result, we should understand "Internet + " at the level of education reform. We can promote the application of dialogue education in the Internet, change the mode and method of education effectively, develop education in a more effective way and accomplish the education reform in a better way through new method of information transmission. The dialogue education performed by virtue of "Internet + " may enable students to study lifelong, so as to make up the insufficiency of traditional education. The combination of "Internet+" and dialogue education will integrate the advantages of the two, and this is conducive to the cultivation of students' information accomplishment, help them to grasp the learning method, learn to study on their own, explore actively, and communicate and cooperate with others. This is bound to be advantageous to the cultivation of innovative talents.

\section{C. "Internet Plus" Changes the Thinking Pattern of Innovative Talents in Dialogue Education}

Internet technology is one of the important ways to change the society and promote social transformation. People's daily life in modern times relies on the Internet more than ever before. Therefore, in order to fit in with the requirement for education in the new era, the methods for education should also keep pace with the times, so as to adapt to the characteristics of Internet era. The dialogue education discussed is the Internet-based teaching activity, so teaching and learning cannot be realized without Internet, and all the dialogues, whether real-time or not, need the support of Internet. This requires both teacher and students to master certain Internet technology. The Internet can provide boundless space for students beyond the limitation of time and space, the boundary of nation, the gap of age, and the field of 
knowledge, so that students may think freely and boundlessly. They can expand their own thinking through communication and interaction with others, and change thinking solidification of Chinese traditional education. Internet can provide abundant information resources for students and offer adequate freedom to students involved in the dialogue. Students can search, screen, analyze and sort out their desired information using Internet, which also reflects individual student's ability to handle information on their own, and cultivates students' innovative thinking. Such dialogue education is personalized education, comprehensive education and exploratory education.

Educators should pay attention to dialogue education, and attach importance to the change of education thinking in the process of teaching, so as to satisfy the thinking pattern of Internet development. Only in this way can they keep pace with the changes of the times and students and cultivate desired talents of the era. The century needs innovationoriented talents. China, in particular, is short of innovative education strength, and the thinking of both educators and learners cannot keep abreast with the times and the state. Under such circumstances, teachers should also change their thinking rapidly using the Internet, so as to keep pace with the students.

\section{Strategies for Innovative Talents Cultivation by Dialogue Education in "Internet Plus" Era}

The Internet era promotes generation and development of many new media, and also facilitates the booming and rapid transmission of information. The dominant position of new media in the information transmission leaves fewer shares for the traditional media. How to select the suitable new media for dialogue teaching when faced by the new media supported by Internet is the issue to be discussed at present. It is our primary task to apply multiple new media to the dialogue education, to discover its different functions, and utilize the new media in a reasonable way.

Taking a panoramic view of various new media, people rely on cell phone more than ever before, and as a newly emerged media, cell phone has become the symbol of the current times. Cell phone is widely by children, youngsters, adults and the elderly in their life, work and learning. If we can apply cell phone into education, and design the teaching and course content that conform to cell phone media transmission, then people can study anywhere and anytime; moreover, cell phone is the tool for our daily communication, so it is more convenient for the dialogue. A company in China develops the "Moso Teach", which integrates cell phone and Internet technology, utilizes "Internet+"dialogue education effectively, and takes cell phone as a medium to perform class teaching. This is an education method of best cost performance at present, and conforms to the concept of lifelong education advocated by the state. Better teaching effect will be obtained with such method, but new requirements for the design, promotion and evaluation of teaching are also put forward.

\section{CONCLUSION}

To sum up, as one of the methods for education, dialogue education has its own charm in the "Internet+" era. Only by developing and using it according to the characteristics of Internet technology can the reform of dialogue education be accomplished, the dialogue education be refreshed, and the innovative talents satisfying the demand of the times be cultivated in this era.

\section{REFERENCES}

[1] Shu Yan. Exploration on Contemporary Dialogue Education Theory [D] Master Thesis of East China Normal University, 2009. (in Chinese)

[2] Duan Yuanping. Paulo Freire Dialogue Education and New Course Reform [J]. Guizhou Education, 2005, (3). (in Chinese)

[3] Zhang Cuiying. Origin and Enlightenment of Dialogue Education [J]. Journal of Puyang Vocational and Technical College, 2012, (6). (in Chinese)

[4] Chen Haiyan. Value Characteristic and Implementation Conditions of Dialogue Teaching in "Internet+ Education" Pattern [J]. The Horizon of Education, 2017, (5). (in Chinese)

[5] Tian Jianjun. Examination of Dialogue Teaching in "Internet" Era [J] Chinese Knowledge, 2016, (19).

[6] Tian Fang. Problems and Strategies in Dialogue Education of College Students [J]. Educator, 2012, (33). (in Chinese)

[7] Zhang Xiaorui. Dialogue Education: Dilemma in Reality and Strategies $[J]$. Journal of Northeast Normal University (Humanities and Socia Sciences), 2014, (2). (in Chinese)

[8] Cheng Yanying. Discussion on Dialogue Mechanism of College Education [D]. Master Thesis of Hunan University, 2012. (in Chinese) 